\title{
Exploring the relationship between social capital, innovation capability and innovation during the coronavirus pandemic
}

\author{
I Gede Cahyadi Putra ${ }^{a}$, Ni Made Sunarsih ${ }^{a}$, Luh Gde Novitasari ${ }^{a}$ and Made Setini ${ }^{b^{*}}$
}

${ }^{a}$ Faculty of Economic and Business, Mahasaraswati Denpasar University, Bali, Indonesia

${ }^{b}$ Faculty of Economics and Busines, Udayana University, Bali, Indonesia

\section{H R O N I C L E}

\begin{tabular}{l}
\hline Article history: \\
Received April 20, 2020 \\
Received in revised format April \\
20,2020 \\
Accepted May 302020 \\
Available online \\
May 312020 \\
\hline Keywords: \\
Cocial capital \\
Business strategy \\
Innovation ability \\
Business success \\
Pandemic Covid-19
\end{tabular}

\section{Introduction}

Bali, Indonesia is a world tourist destination and a magnet for every society. As a center for tourism and the economy, the existence of Micro, Small and Medium Enterprises (MSMEs) has become important in efforts to move the economy. The development of MSMEs in Bali, Indonesia can be said to be productive because it has continued to increase in number over the past five years (Department of Cooperatives and SMEs, December 2019). The development of SMEs in the city of Bali, Indonesia can be said to be productive since it has continued to increase in number over the past five years (Department of Cooperatives and SMEs, December 2019). However, in early 2020 the presence of SMEs in Bali, Indonesia experienced a slowdown, due to the Covid-19 pandemic hit Bali. The direct impact of the pandemic on SMESs was that each resident restricted his/her activities, schools, campuses were closed and residents were advised to remain silent and do work from home. This makes SMEs decrease sales and this can certainly threaten the continuity of the business. In Bali, Indonesia, the SMEs was the most dominant sector affected by Covid-19, with a total of 4,445 (the Office of Cooperatives and SMEs, April 2019). The most affected SMEs are engaged in culinary, such as restaurants, jingo rice traders to market traders. The

* Corresponding author

E-mail address: gitan4nd4@gmail.com (M. Setini)

C 2020 by the authors; licensee Growing Science. doi: $10.5267 /$ j.uscm.2020.5.007

\begin{abstract}
Social restrictions during the pandemic Covid-19 have direct impacts on the survival of Small Medium Enterperises (SMEs), since every citizen limits his/her activities, schools, campuses are closed and residents are advised to remain silent and do work from home. The
purpose of this study is to examine and analyze the effect of social capital, business strategies, and innovation capabilities on business success. The study was conducted in Bali, Indonesia City with 145 samples taken based on a purposive sampling method and data analysis was expand knowledge about customers, raw materials and competitors and is the key to obtain cheap and fast information that is useful for creating innovation. The support of parents, family members and business partners raise the confidence of entrepreneurs to achieve business cess. Business strategy has a positive and significant effect on innovation capability and has no direct effect on success. The findings show that business strategy influences business success through innovation capabilities. At the time of the Covid-19 pandemic the business
strategies developed and implemented by SMEs entrepreneurs in the city of Bali, Indonesia was not able to directly increase business success, but when they developed innovative business strategies, they were able to create something or a new system, unique and accepted by consumers, SMEs entrepreneurs success increases business.
\end{abstract}

(C) 2020 by the authors; license Growing Science, Canada. 
problem faced by entrepreneurs is how to increase sales and profits in the midst of a sluggish economy. SMEs entrepreneurs must have ways and strategies to continue to be able to sustain their business in the midst of a Covid-19 pandemic until it ends. It is in this aspect that the ability of SMEs entrepreneurs is tested to be able to read market opportunities and can further enhance business success. The success of SMEs is strongly influenced by external and internal factors. External factors that influence are economic conditions, natural conditions, infrastructure support, while internal factors are the ability of entrepreneurs to create business networks (O'Regan et al., 2004). The level of extensive social networks is a business success factor obtained by SMEs entrepreneurs. Aldrich and Zimmer (2006) state that the formed business networks can create confidence built through family, closest friends, community, and religion. Man et al. (2002) state that the main factors driving the success of SMEs are the knowledge, skills of owners, and employees. Entrepreneurs who can follow up on business will get a strategic position to be able to develop innovation and create new products. The Covid-19 pandemic caused a decrease of the performance of SMEs, therefore it is necessary to break through policies and strategies of entrepreneurs to be able to survive and improve the competitiveness and performance of SMEs. The ability of innovation is important to be able to survive and be able to compete during the Covid-19 pandemic. A company that can able to innovate allows it to survive and make a profit. Innovation has a major impact on the success of business units and the ability to compete with companies to guarantee the company's ability to face business competition (Gray et al., 2002a, 2002b; Setini el al. 2020). Based on the phenomena and problems above, the purpose of this study is to examine and analyze the impact of social capital, business strategy, and innovation capabilities on the success of SMEs in Bali, Indonesia during the Covid19 pandemic.

\section{Literature Review and Hypothesis Development}

\section{Theory $(R B V)$}

Nothnagel (2008) states that RBV has two assumptions namely resource heterogeneity and resource immobility. Resource heterogeneity reveals whether a company has the resources or capabilities that are also owned by other companies that are the resources are not considered as a competitive advantage. While resource immobility shows the company's resources that are very difficult to obtain by competitors because the price or cost is very expensive. Barney (1991) indicates that a company that has a competitive advantage is when the company implements a value creation strategy that is not simultaneously implemented by current competitors or potential competitors and when other companies cannot duplicate the benefits of the strategy. According to the RBV theory, companies with valuable and rare assets have a competitive advantage and may get superior returns, and those companies whose assets are also difficult to emulate will have sustained superior financial performance (Barney, 1991; Grant 1991).

\section{Social capital}

Social capital is defined as a network, norms, and beliefs social that facilitate mutual coordination and cooperation (Putnam et al., 1994). Social capital can be described as a series of informal values that are shared between members of a group that allows for cooperation. Social capital is a series of processes of relations between human parents, family, or friends supported by a network of social norms and beliefs that enables the efficiency and effectiveness of coordination and cooperation (Cox, 2006).

\section{Business Strategy}

The strategy is a pattern of resource allocation that allows companies to maintain their business in business units (Barney, 1997). Business strategy has two dimensions; namely competitive and partner strategy. Competitive strategy is the company's strategy in the search for a favorable competitive position in an industry. Partner strategy is a business strategy that is carried out by two or more parties to achieve mutual benefits within a certain period with the principle of mutual need and mutual encouragement.

\section{Innovation Capability}

The concept of innovation includes product innovation, process innovation, organizational innovation, and business innovation (Dealtry \& Rademakers, 2005). Innovation is a process that is not only limited to the creation of new ideas but also it is associated with the ideas or thoughts which are implemented through an adoption process (Giantari et al., 2020). The ability to innovate an entrepreneur is influenced by internal and external factors (Romjin \& Albaladejo, 2000). Internal factors include different items such as the level of education and experience of the owner, the skills technical workers, research and development institutions, and investment in training and human resource development. While external factors include support financial from the government for research and development, communication, or interaction with outside parties such as suppliers, customers, competitors, financial institutions, and industry associations.

\section{Business Success}

Achieving company goals is a success. Success can be interpreted as a tool that measures the results of the company's activities during a certain period achieved about certain standards. Business success is an economic situation that has increased and strengthened in certain periods (Unger et al., 2011). Business success can be seen from success in competition, 
increasing company assets, and success in developing new products and in the financial aspects of sales growth and increased profitability (Suhairi, 2002; Yasa et al. 2020).

\section{Social capital relationships, business strategies, innovation capabilities, and business success}

Social capital is a unique company asset that is related to its structure socially and can be used to impart knowledge and implement it (Edvinsson \& Malone, 2007). Knowledge is very important in establishing routines and procedures for doing business. Companies through knowledge can participate in network activities regarding the potential to create and expand knowledge about customers, raw materials, and competitors. Social capital is used to enhance knowledge about learning, economic knowledge, understanding the strengths and status of individuals (Bourdieu \& Wacquant, 2007) as well as being the key for creativity and business strategies of business actors (Gulati, 2005). Social networks in social capital are built based on friendship, kinship, geographical closeness, so entrepreneurs can get cheap and fast information on the market. High social capital can increase the ability of entrepreneurs to be the first in identifying new trends and trying to develop new products. Information in the network that has been built such as customer demand, evaluating the strength of competitors, advertising, and service to customers is the basis for entrepreneurs to innovate. Dutta's research (2013) found at a certain point that social capital can play a beneficial role by increasing the ability of corporate innovation. Furthermore Dutta (2013) argues that social capital has a positive effect on the ability of innovation and follows non-linear relationships. Social capital is a resource available within the organization and is obtained through personal relations networks and business networks (Coleman, 2008). Social capital owned by the company will determine the effectiveness of the communication that determines the form of support and cooperation to create trust in running a business. Support from parents, family members, and business partners can create confidence in entrepreneurs in managing their business. Cook and Whitmeyer (1992) found that social capital had a significant positive effect on business success. Furthermore, Cook and Whitmeyer (1992) also stated that the role of people, family, marriage, neighbors, and friends are close through a bonding structure facilitates exchanging ideas and bridging, that satisfaction when receiving support is proven to bring success to entrepreneurs. The condition of a competitive and uncertain business environment as experienced by businesses currently being hit by the Covid-19 pandemic. Conditions like this will continue to increase and tend to experience high intensity, which makes entrepreneurs think that business management must survive and thrive in such a business environment. Entrepreneurs need to think of the right business strategy to make a breakthrough by creating opportunities for innovative ideas. The business decision-making process should not rely on mechanical thought patterns and intuition, but use the concept of strategic thinking in creating a competitive advantage. The strategy is a process of determining an entrepreneur's plan that focuses on long-term goals, accompanied by the design of how those goals can be achieved. The strategy is how the vision and mission in the current conditions are compared with what is expected. The results of Panell's research (2010) produced findings that the combination strategy implemented by the company had a positive relationship with the company's performance. The ability of innovation is an absolute must for entrepreneurs to face the situation during the Covid-19 pandemic. The ability to innovate gives a guarantee that a company can survive and compete to create business success. Lee and Tsai (2005) found the relationship between innovation ability and company performance was positive and significant. Parkman et al. (2012) found that the company's innovation ability had a positive and significant effect on the success of a product produced. Scott and Chaston (2012) provide empirical evidence that innovation can improve product performance and extend the company's life cycle in Peru. Based on the relationship of variables explained above, the hypothesis developed in this study is.

H1: Social capital has a positive effect on innovation ability. H2: Social capital has a positive effect on business success. H3: Social capital has a positive effect on business success.
H4: Business strategy has a positive effect on innovation ability. H5: Business strategy has a positive effect on business success. H6: Innovative ability affects positive on business success.

Based on the theory and study of the results of previous studies, the framework of the research concept in Fig. 1.

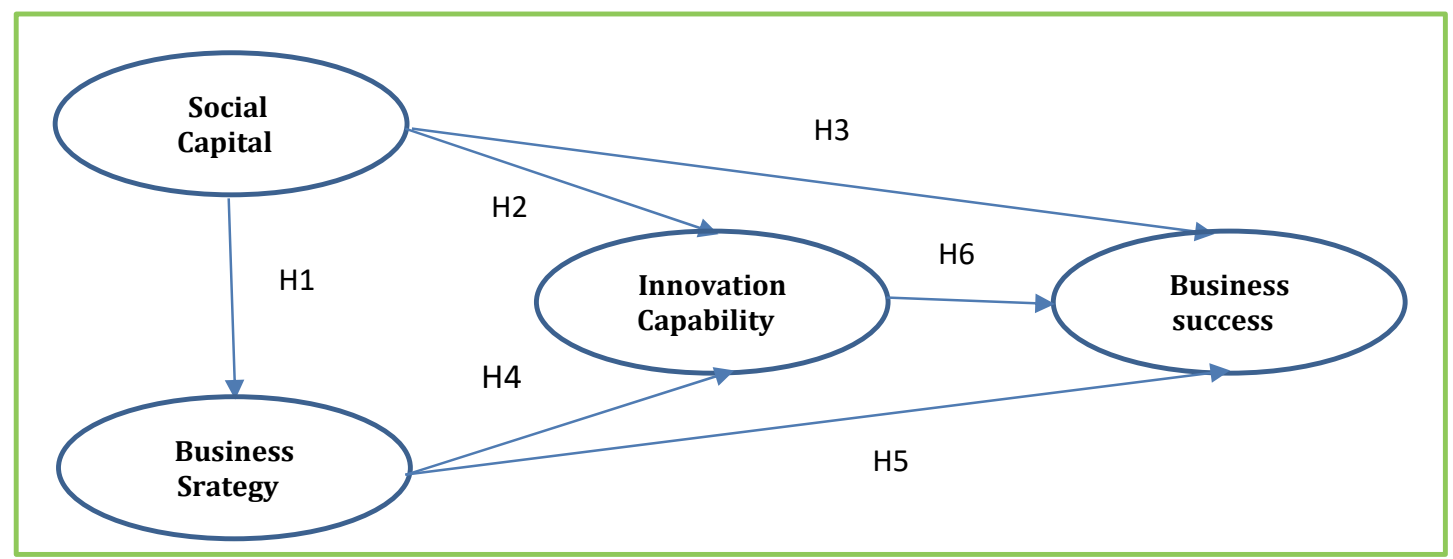

Fig. 1. The proposed study 


\section{Method}

This research was conducted in micro small and medium enterprises in Bali, as many as 326,009 business units (Department of Cooperatives and SMEs, 2019).. The method of determining the sample using the method of purposive sampling is the method of sampling with criteria certain. The sample used was the owners of micro and small businesses that were directly affected by the Covid-19 pandemic. The number of samples is calculated based on Hair (2017), which is 5 to 10 times the number of indicators. The indicators in this study were 29 question items, so the total sample was 145 respondents (multiplied by 5). Research instruments were collected using a questionnaire distributed online. Data analysis techniques using SEM-PLS. This research is predictive so that an approach based on variance such as PLS is more suitable for use (Ghozali, 2011).

\section{Results}

Assessment of the outer model is carried out to determine the validity and reliability of the indicators and latent variables of the study. Validity is known by using convergent validity and discriminant validity. While reliability is known by using the value of indicator reliability and the value of internal consistency reliability. The convergent validity value is known from the loading factor and discriminant validity through the AVE value (Average Variance Extracted). The factor loading value of all measurement indicators is above 0.5 and the value of AVE for all research variables is also above 0.5. This figure shows that all measurement indicators meet the convergent validity provisions and each indicator is valid in measuring the relevant variables. Reliability testing uses composite reliability values and Cronbach alpha values with all indicators above 0.7 , which means that all latent variables have consistent and reliable results. A summary of the results of testing the validity and reliability as in Table 1.

Table 1

Test the validity and reliability

\begin{tabular}{|c|c|c|c|c|c|}
\hline Variabel/Indicator & Outer Loading & $\begin{array}{l}\text { Average Variance } \\
\text { Extracted (AVE) }\end{array}$ & $\begin{array}{l}\text { Composite } \\
\text { Reliability }\end{array}$ & Cronbach's Alpha & Explanation \\
\hline Social capital (X1) & & \multirow{7}{*}{0.519} & \multirow{7}{*}{0,915} & \multirow{7}{*}{0.897} & \multirow{7}{*}{ Valid and reliable } \\
\hline $\mathrm{X} 1.1$ & 0.77 & & & & \\
\hline $\mathrm{X} 1.2$ & 0.75 & & & & \\
\hline $\mathrm{X} 1.3$ & 0.817 & & & & \\
\hline $\mathrm{X} 1.4$ & 0.814 & & & & \\
\hline $\mathrm{X} 1.5$ & 0.768 & & & & \\
\hline $\mathrm{X} 1.6$ & 0.714 & & & & \\
\hline \multicolumn{2}{|c|}{ Business Strategy (Y1) } & \multirow{11}{*}{0.674} & \multirow{11}{*}{0.892} & \multirow{11}{*}{0.838} & \multirow{11}{*}{ Valid and reliable } \\
\hline Y1.1 & 0.631 & & & & \\
\hline Y1.2 & 0.774 & & & & \\
\hline Y1.3 & 0.673 & & & & \\
\hline Y1.4 & 0.698 & & & & \\
\hline Y1.5 & 0.731 & & & & \\
\hline Y1.6 & 0.767 & & & & \\
\hline Y1.7 & 0.694 & & & & \\
\hline Y1.8 & 0.713 & & & & \\
\hline Y1.9 & 0.714 & & & & \\
\hline $\mathrm{Y} 1.10$ & 0.793 & & & & \\
\hline \multicolumn{6}{|c|}{ Innovation capability (Y2) } \\
\hline Y 2.1 & 0.803 & \multirow{9}{*}{0.592} & \multirow{9}{*}{0.928} & \multirow{9}{*}{0.913} & \multirow{9}{*}{ Valid and reliable } \\
\hline Y 2.2 & 0.67 & & & & \\
\hline Y 2.3 & 0.806 & & & & \\
\hline Y 2.4 & 0.841 & & & & \\
\hline Y2.5 & 0.735 & & & & \\
\hline Y2.6 & 0.703 & & & & \\
\hline Y2.7 & 0.743 & & & & \\
\hline Y 2.8 & 0.815 & & & & \\
\hline Y2.9 & 0.791 & & & & \\
\hline \multicolumn{6}{|c|}{ Business Success (Y3) } \\
\hline Y3.1 & 0.857 & \multirow{4}{*}{0.597} & \multirow{4}{*}{0.899} & \multirow{4}{*}{0.865} & \multirow{4}{*}{ Valid and reliable } \\
\hline Y3.2 & 0.768 & & & & \\
\hline Y3.3 & 0.809 & & & & \\
\hline Y3.4 & 0.846 & & & & \\
\hline
\end{tabular}

This study examined three variables dependent, namely business strategy, innovation capability, and business success. The following are the values of each R Square as shown in Table 2. Based on Table 2 above obtained R square values for the business strategy variable of 0.495 or 49.5 percent of the variation of the business strategy can be explained by social capital and the remaining 50.5 percent is explained by other variables outside the study. The value of the $\mathrm{R}$ square variable innovation capability is 0.558 , meaning that 55.8 percent of variations of innovation capability can be explained by social capital and business strategy and the remaining 44.2 percent is explained by other variables outside the study. R-square 
value for the variable business success for 0660, it shows that 66 percent of the variation of business success can be explained by social capital, business strategy, and innovation capability, while the rest of 34 percent is explained by other variables outside the research.

Table 2

Value coefficients of R-Square

\begin{tabular}{lll}
\hline Variable & R Square & R Square Adjusted \\
\hline Business Strategy (Y1) & 0.495 & 0.490 \\
Innovation capability (Y2) & 0.558 & 0.548 \\
Business Success (Y3) & 0.660 & 0.649 \\
\hline
\end{tabular}

The value of $\mathrm{Q}$ square $\left(\mathrm{Q}^{2}\right)$ predictive relevance in a structural model is used to measure how well the value of observations is produced by the model and also the estimated parameters. Q square value is calculated by the formula:

$$
\mathrm{Q}^{2}=1-(1-\mathrm{R} 12)(1-\mathrm{R} 22)(1-\mathrm{R} 32)=1-0.182=0.818
$$

The value of $\mathrm{Q}^{2}$ has a value in the range $0<\mathrm{Q}^{2}<1$, were closer to 1 means a better model. The calculation results obtained from Q2 are 0.818, so it can be concluded that the model has predictive relevance. Thus, it can be explained that 81.8 percent of the variation in SMES business success in the city of Bali, Indonesia is influenced by social capital, business strategy, and innovation capability, while the remaining 18.2 percent is influenced by other variables outside the research model.

\section{Discussion}

Acceptance of hypotheses can be calculated from the results of the path coefficient and the significance of the model based on $t$ statistics and p values. Hypothesis testing results are as shown in Fig. 2 and Table 3 below.

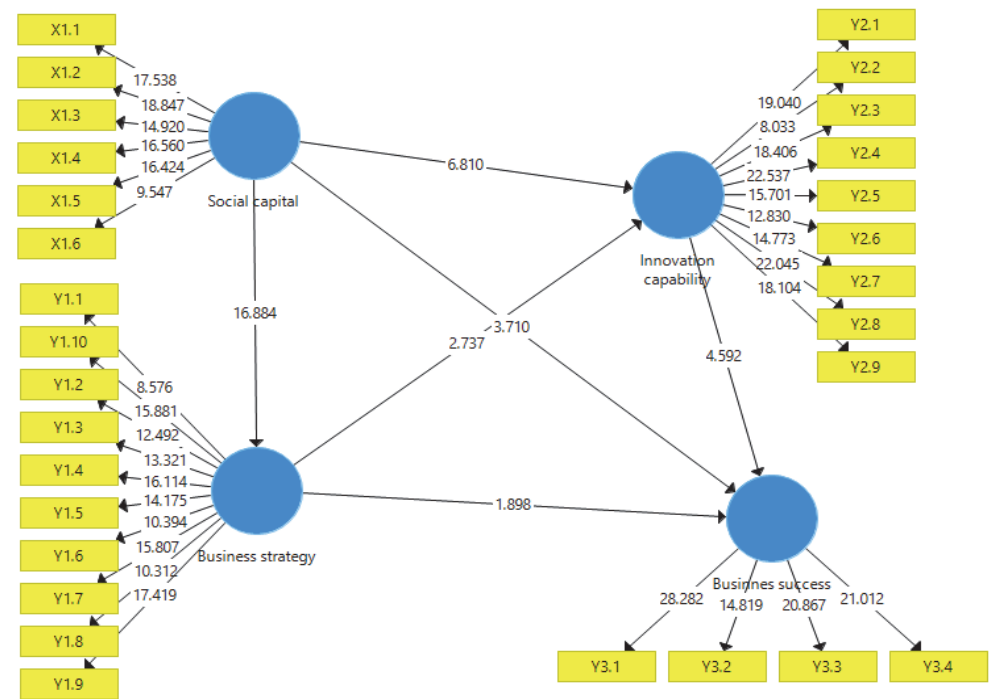

Fig. 2. Measurement Model of PLS Results Source: author's calculations.

Table 3

Path Coefficients

\begin{tabular}{lllll}
\hline Between Path Variables & Coefficient & t Statistics & p-Value & Information \\
\hline Social capital $\rightarrow$ Business strategy & 0.704 & 16.884 & 0.000 & Positive and Significant \\
Social capital $\rightarrow$ Innovation capability & 0.547 & 6.810 & 0.000 & Positive and Significant \\
Social capital $\rightarrow$ Business success & 0.357 & 3.710 & 0.000 & Positive and Significant \\
Business strategy $\rightarrow$ Innovation capability & 0.252 & 2.737 & 0.006 & Positive and Significant \\
Business strategy $\rightarrow$ Business success & 0.160 & 1.898 & 0.058 & Positive and Not Significant \\
Innovation capability $\rightarrow$ Business success & 0.384 & 4.592 & 0.000 & Positive and Significant \\
\hline
\end{tabular}

Based on the results of the path coefficient in Table 3, it can be explained the results of the research hypothesis as follows. 
Based on the results of the analysis we have obtained the coefficient of social capital on business strategy as 0.707 with a $t$ value of 16.884 ( $\mathrm{t}$ statistics $>1.96$ ) and $\mathrm{p}$-value of 0.000 ( $\mathrm{p}$-value $<0.05$ ). This shows the first hypothesis is accepted, which means that social capital has a positive and significant effect on business strategy. These findings indicate that social capital had an important contribution on developing a business strategy. In social capital there is trust, and compliance between partners can realize mutually beneficial cooperation. Partner strategies can be developed by SMEs' actors to obtain information so that there are opportunities for long-term and profitable cooperation.

\section{Effect of social capital on innovation capability}

Based on the results of the analysis we have obtained, the coefficient of social capital on innovation capability is 0.547 with a t-statistic value of 6.810 ( $\mathrm{t}$ statistic $>1.96$ ) and a p-value of 0.000 ( $\mathrm{p}$-value $<0.05$ ). This shows the second hypothesis is accepted, this means that social capital has a positive and significant effect on innovation capability. Strong social capital in social networks based on friendship, kinship, geographical proximity can provide fast and inexpensive information. More and more quality information can improve the ability of businesses to innovate, identify new trends, and develop marketing systems and new product development. The results of this study are in line with the results of research conducted by Dutta (2013).

\section{Effect of social capital on business success}

Based on the results of the analysis obtained the coefficient of social capital on the business success is equal to 0.357 with a t-statistic value of 3.710 ( $\mathrm{t}$ statistic $>1.96$ ) and a p-value of 0.000 (p-value $<0.05$ ). This shows the third hypothesis is accepted, which means that social capital had a positive and significant effect on business success. The results showed that social capital in the form of support from parents, family members, and business partners can raise the confidence of SMEs entrepreneurs in managing their business. This confidence can generate an entrepreneur's passion and enthusiasm to do the best in his business so that success can be achieved. The results of this study are in line with the results of research conducted by Cook et al. (1992).

\section{Effect of business strategy on innovation capability}

Based on the results of the analysis, the coefficient of business strategy on innovation capability is 0.252 with a t value of 2.738 ( $\mathrm{t}$ statistics $>1.96$ ) and a p-value of 0.006 ( $\mathrm{p}$-value $<0.05)$. This shows the fourth hypothesis is accepted, which means that business strategy has a positive and significant effect on innovation capability. These results indicate that the co-19 pandemic conditions create uncertainty in the business climate for SMEs. SMEs entrepreneurs in the city of Bali, Indonesia have been able to innovate in developing strategies through competitive strategies and partnership strategies to build a communication network with suppliers and create marketing strategies tailored to the conditions of the co-19 pandemic so that sales of products and services remain stable.

\section{Effect of business strategy on business success}

Based on the analysis results, the coefficient of business strategy on innovation capability is 0.160 with a t value of 1.898 ( $t$ statistic $<1.96$ ) and a $p$-value of 0.058 ( $p$ value $>0.05$ ). This shows that the fifth hypothesis is rejected; which means that business strategy has no significant effect on business success. These findings indicate that at the time of the Covid-19 pandemic the business strategies developed and implemented by SMEs entrepreneurs in the city of Bali, Indonesia were unable to directly increase business success. Based on the analysis results obtained that business strategy influences business success through innovation capabilities. The business strategy developed must be able to create an innovation that is something or a new, unique system that can be accepted by consumers. Covid-19 pandemic requires entrepreneurs to develop strategies such as adjusting sales methods, adjusting products by prioritizing relevant products and must increase the use of technology. The results of this study are not in line with the findings of Panell's (2010) study.

\section{Innovation capability for business success}

Based on the results of the analysis obtained the value of the innovation capability coefficient for business success is 0.384 with a t value of 4.592 ( $\mathrm{t}$ statistics $>1.96$ ) and a p-value of 0.000 ( $\mathrm{p}$-value $<0.05$ ). This shows that the sixth hypothesis is accepted, which means that innovation capability has a positive and significant effect on business success. These results indicate that the high innovation capability possessed by SMEs entrepreneurs in the city of Bali, Indonesia has been able to bring and maintain sales and business profit stability amid the co-19 pandemic. The results of the study are in line with research conducted by Parkman et al. (2012) and Scott and Chaston (2012).

\section{Conclusions and Recommendations}

Based on the results of the discussion, it can be concluded that social capital has a positive and significant effect on business strategy, innovation capability, and business success of SMEs in Bali, Indonesia during the Covid-19 pandemic. Social capital owned by SMEs entrepreneurs can create and expand knowledge about customers, raw materials, and competitors as well as being the key to obtaine cheap and fast information that is useful for creating innovation. The support of parents, 
family members, and business partners raise the confidence of entrepreneurs in managing their business, so that business success is achieved during the Covid-19 pandemic. Business strategy has a significant positive effect on innovation capability and does not directly influence the success of SMEs businesses. The findings show that Business strategy influences business success through innovation capabilities. At the time of the Covid-19 pandemic the business strategies developed and implemented by SMEs entrepreneurs in the city of Bali, Indonesia was not able to directly increase business success, but when the strategies adopted were able to create innovation, create something or a new, unique system and confirmed by consumers, then they can increase the business success of SMEs. The results of the study have implications that in the Covid-19 pandemic, entrepreneurs are still able to survive and achieve business success by good management of social capital and develop appropriate business strategies to produce innovation for both products and business networks. Future studies can examine the human factors in the form of human capital owned by SMEs entrepreneurs in developing business knowledge and strategies to achieve success in their businesses.

\section{References}

Barney, J.B. (1991). Firm resources and sustained competitive advantage. Journal of Management, 17, 99-120.

Barney, J.B. (1997). Gaining and Sustaining Competitive Advantage. Reading, Massachusetts: Addison-Wesley Publishing Company.

Bourdieu, P. \& Wacquant, L.J.D. (2007). An Invitation to Reflexive Sociology. Chicago: University of Chicago Press.

Coleman, J.S. (2008). Foundations of Social Theory. Cambridge, Belknap Press.USA.

Cook, K.S., \& Whitmeyer, J.M. (1992). Two approaches to social structure: Exchange theory and network analysis. Annual Review of Sociology, 18(1), 109-127.

Cox, E. (2006). A Truly Civil Society. Sydney: ABC Book Cooper, DF, and CW, Emory (1996), Business Research Method, 5th Edition, Richard D. Irwin, Inc., USA.

Dutta, D.K. (2013). Benefiting from your buddy. American Journal of Business, 28(2), 192-209.

Edvinsson, L., \& Malone, M.S. (2007). Human Capital and Competitiveness guideLine For Policy. Competitiveness Review, 10(2), 192

Ghozali, I. (2011). Structural Equation Modeling - Alternative Methods with Partial Least Square (PLS). Issue 3. Semarang: Diponegoro University Publisher Board.

Grant, R.M. (1991). The resource-based theory of competitive advantage: Implications for strategy formulation. California Management Review, 33(3), 114-135.

Gray, B. J., Matear, S., \& Matheson, P.K. (2002a). Improving the performance of hospitality firm. International Journal of Contemporary Hospitality Management, 12(3), 149-155.

Gray, B. J., Matear, S., \& Matheson, P. K. (2002b). Improving service firm performance. Journal of Services Marketing, $16(3), 186-200$.

Giantari, I. G. A. K., \& Widagda, I. G. N. J. A. (2020). Symbiosis mutualism village credit institutions and business strategies in Bali Indonesia. Journal of Talent Development and Excellence, 12(1), 01-14.

Gulati, R. (2005). Alliances and strategic networks. Management Journal, 19, 293-317

Hair, J., Hollingsworth, C. L., Randolph, A. B., \& Chong, A. Y. L. (2017). An updated and expanded assessment of PLSSEM in information systems research. Industrial Management \& Data Systems.

http://ukmdiskop.denpasarkota.go.id/ accessed on March 26, 2020.

Lee, T. S., \& Tsai, H. J. (2005). The effects of business operation mode on market orientation, learning orientation and innovativeness. Industrial Management \& Data Systems, 105(3), 325-348.

Putnam, R. D., Leonardi, R., \& Nanetti, R. Y. (1994). Making democracy work: Civic traditions in modern Italy. Princeton university press.

Nothnagel, K. (2008). Empirical research within resource-based theory: A meta-analysis of the central propositions. Springer Science \& Business Media.

Parkman, I. D., Holloway, S. S., \& Sebastiao, H. (2012). Creative industries: aligning entrepreneurial orientation and innovation capacity. Journal of Research in Marketing and Entrepreneurship.

Parnell, J. A. (2010). Strategic clarity, business strategy and performance. Journal of Strategy and Management, 3(4), 304324.

Dealtry, R., \& Rademakers, M. (2005). Corporate universities: driving force of knowledge innovation. Journal of Workplace Learning.

Romjin, H., \& Albaladejo, M. (2000). Determinant of Innovation Capability in Small UK Firms: An Empirical Analysis, QEH Working Paper Series QEH PS40, Number 40.

Setini, M., Yasa, N. N. K., Gede Supartha, I. W., Ketut Giantari, I., \& Rajiani, I. (2020). The passway of women entrepreneurship: Starting from social capital with open innovation, through to knowledge sharing and innovative performance. Journal of Open Innovation: Technology, Market, and Complexity, 6(2), 25.

Suhairi. (2002). Effect of entrepreneurial competence and the use of accounting information in using accounting information in making company selling price decisions; Cases in the medium scale manufacturing industry in Indonesia. Journal of accounting and business. 3(2), 1-12. 
Unger, J. M., Rauch, A., Frese, M., \& Rosenbusch, N. (2011). Human capital and entrepreneurial success: A meta-analytical review. Journal of business venturing, 26(3), 341-358.

Scott, G. J., \& Chaston, I. (2013). Culture and Innovation in Peru from a Management Perspective. Journal of Global Initiatives: Policy, Pedagogy, Perspective, 7(2), 10.

Yasa, N., Giantari, I., Setini, M., \& Rahmayanti, P. (2020). The role of competitive advantage in mediating the effect of promotional strategy on marketing performance. Management Science Letters, 10(12), 2845-2848.

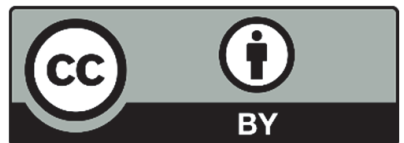

(C) 2020 by the authors; licensee Growing Science, Canada. This is an open access article distributed under the terms and conditions of the Creative Commons Attribution (CC-BY) license (http://creativecommons.org/licenses/by/4.0/). 